\title{
PERBEDAAN KEMAMPUAN KOMUNIKASI MATEMATIS SISWA MENGGUNAKAN MODEL PEMBELAJARAN KOOPERATIF TIPE TPS DENGAN TIPE NHT SMP NEGERI 2 HINAI
}

\author{
${ }^{1}$ Ariati Dara Anindita, ${ }^{2}$ Humuntal Banjarnahor \\ ${ }^{1}$ Fakultas Matematika dan Ilmu Pengetahuan Alam, Universitas Negeri Medan \\ ${ }^{2}$ Dosen Fakultas Matematika dan Ilmu Pengetahuan Alam, Universitas Negeri Medan \\ Email: ariati.d53@yahoo.com
}

\begin{abstract}
ABSTRAK
Penelitian ini bertujuan untuk mengetahui kemampuan komunikasi matematis siswa menggunakan model pembelajaran kooperatif tipe TPS dengan kemampuan komunikasi matematis siswa menggunakan model pembelajaran kooperatif tipe NHT, dan untuk mengetahui apakah kemampuan komunikasi matematis siswa dengan pembelajaran kooperatif tipe TPS lebih tinggi daripada tipe NHT SMP Negeri 2 Hinai. Penelitian ini merupakan penelitian quasi experimental dengan populasi seluruh siswa SMP Negeri 2 Hinai kelas VIII, sebagai sampel diambil dua kelas secara acak yaitu siswa kelas VIII-A yang berjumlah 34 siswa sebagai kelas eksperimen 1 dan siswa kelas VIII-D yang berjumlah 34 siswa sebagai kelas eksperimen 2. Kelas eksperimen 1 diberikan pembelajaran matematika dengan model pembelajaran kooperatif tipe TPS dan kelas eksperimen 2 dengan model pembelajaran kooperatif tipe NHT. Penelitian ini menggunakan satu jenis instrument yaitu post-test only yang telah divalidasi dalam bentuk uraian. Hasil penelitian menunjukkan bahwa rata-rata nilai kemampuan komunikasi matematis (post-test) siswa di kelas eksperimen 1 sebesar 67,01 dan nilai rata-rata tes kemampuan komunikasi matematis (post-test) siswa di kelas eksperimen 2 sebesar 60,54. Untuk uji hipotesis digunakan uji t pihak kanan, dari hasil perhitungan diperoleh $t_{\text {hitung }}=1,913$ dan $t_{\text {tabel }}=1,669$, sehingga $t_{\text {hitung }}>t_{\text {tabel }}$ yaitu $1,913>1,669$ maka yang berarti bahwa $H_{0}$ ditolak dan $H_{a}$ diterima. Berdasarkan hasil penelitian tersebut dapat disimpulkan bahwa kemampuan komunikasi matematis siswa menggunakan model pembelajaran kooperatif tipe TPS lebih tinggi daripada kemampuan komunikasi matematis siswa menggunakan model pembelajaran kooperatif tipe NHT SMP Negeri 2 Hinai.
\end{abstract}

Kata Kunci: eksperimen semu, Think Pair Share , Numbered Head Together

\begin{abstract}
This research to determine students 'mathematical communication ability using cooperative learning model of TPS type with students' mathematical communication ability using NHT type cooperative learning model, and to know whether the mathematical communication ability of students with cooperative learning type of TPS is higher than NHT type SMP Negeri 2 Hinai. This research is a quasi experimental research with population of all students of SMPN 2 Hinai Class VIII, as sample taken by two classes randomly that is student of class VIII-A which amounted to 34 students as experiment class 1 and student of class VIII-D Amounted to 34 students as experiment class 2. Experiment class 1 was given mathematics learning with cooperative type model of TPS type and experiment class 2 with cooperative learning model type NHT. This study uses one type of instrument that is post-test only that has been validated in the form of a description. The results showed that the average score of mathematical communication
\end{abstract}

Ariati Dara Anindita, Humuntal Banjarnahor. Perbedaan Kemampuan Komunikasi Matematis Siswa Menggunakan Model Pembelajaran Kooperatif Tipe TPS dengan Tipe NHT SMP Negeri 2 Hinai. Jurnal Inspiratif, Vol. 3 No. 2 Agustus 2017. 
ability (post-test) of students in experiment class 1 was 67.01 and the mean score of students' mathematical communication ability (post-test) in experimental class 2 was 60,54. To test the hypothesis used t right side test, from the calculation result obtained tcount $=1.913$ and ttable $=1.669$, so $t_{\text {count }}>t_{\text {table }}$ is $1.913>1.669$ then that means that $H_{0}$ rejected and $H_{a}$ accepted. Based on the results of this study can be concluded that the mathematical communication skills of students using cooperative learning model of TPS type higher than students' mathematical communication skills using cooperative learning model type NHT SMP Negeri 2 Hinai.

Keywords: Quasi Experiments,Think Pair Share, Numbered Head Together

\section{Pendahuluan}

Pendidikan merupakan hal yang
sangat penting untuk menjamin
kelangsungan hidup bangsa dan negara,
karena dengan adanya pendidikan dapat
meningkatkan dan mengembangkan
kualitas sumber daya manusia.
Pendidikan juga merupakan faktor
pendukung dalam perkembangan dan
persaingan dalam berbagai bidang. Seperti halnya yang diungkapkan Trianto (2009:1) bahwa : "Pendidikan yang mampu mendukung pembangunan di masa mendatang adalah pendidikan yang mampu mengembangkan potensi peserta didik, sehingga mampu memecahkan problema kehidupan yang dihadapinya".

Salah satu pendidikan yang dianggap penting untuk meningkatkan dan mengembangkan kualitas sumber daya manusia adalah pendidikan matematika. Pendidikan matematika mempunyai peranan bagi setiap individu untuk melatih kemampuan berfikir logis, kritis, sistematis, kreatif dan kemauan bekerja sama yang efektif. Cara berpikir seperti ini yang dapat dikembangkan melalui pendidikan matematika karena matematika memiliki struktur dengan keterkaitan yang kuat dan jelas antara yang satu dengan yang lainnya, serta memerlukan pola pikir yang bersifat deduktif dan konsisten. Hal ini sesuai dengan banyaknya pendapat yang telah disumbangkan matematika untuk kemajuan peradaban manusia. pendidikan matematika dapat menata nalar siswa agar mereka menjadi siswa yang berpikir kritis karena dalam proses pembelajaran matematika daya nalar siswa senantiasa diasah. Dengan tujuan yang bersifat material tersebut siswa dapat menerapkan materi yang dipelajari dalam kehidupan sehari-hari dan mereka dapat memecahkan soalsoal matematika (Surya, 2017).

Dengan belajar matematika seseorang mampu mengomunikasikan gagasan, kemampuan berkomunikasi menjadi kemampuan yang penting dalam pembelajaran matematika dan bidang ilmu lainnya. Dalam belajar matematika dituntut untuk mampu membaca konsep-konsep matematika yang penuh dengan simbol-simbol, selanjutnya memahami makna yang terkadung dalam simbol itu ke dalam satu konsep yang utuh, dan menyusun konsep itu ke dalam bahasa sendiri sesuai dengan tingkat perkembangan intelektualnya. Dalam penerapan konsep matematika yang dipelajari, didukung oleh kemampuan penalaran dan komunikasi yang relevan. Komunikasi yang dimaksud adalah kemampuan dalam menafsirkan gagasan matematika baik secara lisan, tertulis juga demonstrasi. Hal ini sesuai dengan pendapat Ojose (2011) menyatakan bahwa seseorang yang mempunyai literasi matematis dapat menafsirkan data, memecahkan masalah sehari-hari, alasan dalam situasi numerik, grafis, dan geometris,serta berkomunikasi dengan menggunakan matematika.

Melalui komunikasi matematis siswa dapat mengorganisasi dan mengkolidasi berpikir matematisnya baik secara lisan maupun tulisan, disamping renegoisasi respon antar siswa akan dapat terjadi dalam proses pembelajaran. Pada akhirnya komunikasi matematis dapat

Ariati Dara Anindita, Humuntal Banjarnahor. Perbedaan Kemampuan Komunikasi Matematis Siswa Menggunakan Model Pembelajaran Kooperatif Tipe TPS dengan Tipe NHT SMP Negeri 2 Hinai. Jurnal Inspiratif, Vol. 3 No. 2 Agustus 2017. 
membawa siswa pada pemahaman yang mendalam tentang konsep matematika yang telah dipelajari (Martunis, 2014 :76). Kemampuan berkomunikasi siswa dalam pembelajaran matematika perlu menjadi fokus perhatian. Hal ini dikarenakan melalui komunikasi matematis siswa dapat mengeksplorasi ide-ide matematikanya. Oleh karena itu, siswa perlu dibiasakan memberikan argumen terhadap setiap jawabannya serta memberikan tanggapan atas jawaban yang diberikan orang lain, sehingga apa yang sedang dipelajari menjadi bermakna baginya.

Hal ini tentu menggambarkan
bahwa kemampuan matematis juga dapat menjadi suatu sarana bertukar pendapat maupun mengklarifikasi terhadap suatu konsep yang siswa pahami. Ketika sebuah konsep informasi matematika diberikan oleh seorang guru kepada siswa ataupun siswa mendapatkannya sendiri melalui bacaan, maka saat itu sedang terjadi transformasi informasi matematika dari komunikator kepada komunikan. Respon yang diberikan komunikan merupakan interpretasi komunikan tentang informasi tadi. Dalam matematika, kualitas interpretasi dan respon itu seringkali menjadi masalah istimewa. Hal ini sebagai salah satu akibat dari karakteristik matematika itu sendiri yang sarat dengan istilah dan simbol. Karena itu, kemampuan berkomunikasi dalam matematika menjadi tuntutan khusus. Kenyataan dilapangan menunjukkan bahwa kemampuan komunikasi matematis siswa di Indonesia masih rendah. Sebagaimana yang ada pada penelitian Sefalianti (2014: 12) “ Pada PISA 2009, skor matematika siswa Indonesia 371 dan berada pada posisi 61 dari 65 negara. Hanya $0,1 \%$ siswa Indonesia yang mampu mengembangkan dan menegerjakan permodelan matematika". Dalam hal ini berarti siswa belum biasa mengerjakan soal yang menuntut siswa untuk mencari hasil beserta asal-usul atau langkah - langkah pengerjaannya. Kemampuan komunikasi matematis menunjang kemampuan- kemampuan matematis yang lain, misalnya kemampuan pemecahan masalah. Surya (2013) mengemukakan kesulitan yang diperoleh siswa adalah pada saat memahami, menggambar diagram, membaca grafik dengan benar, pemahaman konsep matematika formal, dan penyelesaian masalah matematika. Penyajian masalah yang tepat adalah hal mendasar dalam memahami masalah tersebut dan membuat rencana untuk menyelesaikannya.

Dengan kemampuan komunikasi yang baik maka suatu masalah akan lebih cepat bisa direpresentasikan dengan benar dan hal ini akan mendukung untuk penyelesaian masalah. (Martunis, 2014 :76) mengatakan bahwa "Seorang siswa yang tidak mampu memahami suatu ide matematis, maka akan sulit baginya untuk mengkomunikasikan ide tersebut baik secara lisan ataupun tulisan. Ketidakmampuan siswa dalam mengkomunikasikan ide akan mengakibatkan siswa tidak mampu mengerjakan soal-soal atau permasalahan sehingga berdampak pada rendahnya prestasi siswa". Menyadari hal tersebut, dapat dikatakan bahwa komunikasi matematis sangat diperlukan dalam proses keberhasilan pembelajaran matematika.

Kemampuan komunikasi matematis yang rendah tersebut akibat dari respons siswa terhadap soal-soal komunikasi matematis umumnya kurang. Selain itu juga, disebabkan karena guru terlalu banyak menerangkan, sehingga suasana di dalam kelas menjadi tegang. Oleh karena itu, penting bagi guru untuk mengetahui kemampuan komunikasi matematis peserta didik dalam suatu pembelajaran matematika. Dengan mengetahui kemampuan komunikasi matematis peserta didik, guru dapat melacak dan menyelidiki seberapa jauh pemahaman matematis dan letak kesalahan konsep peserta didik.

Banyak faktor yang mempengaruhi rendahnya nilai matematika pada siswa. Hal ini sesuai dengan penelitian yang dilakukan oleh Darkasyi (2014 : 22) memperlihatkan

Ariati Dara Anindita, Humuntal Banjarnahor. Perbedaan Kemampuan Komunikasi Matematis Siswa Menggunakan Model Pembelajaran Kooperatif Tipe TPS dengan Tipe NHT SMP Negeri 2 Hinai. Jurnal Inspiratif, Vol. 3 No. 2 Agustus 2017. 
bahwa "Rendahnya komunikasi matematis di Sekolah Menengah Pertama (SMP) disebabkan guru masih cenderung aktif dengan pendekatan ceramah menyampaikan materi kepada peserta didik sehingga siswa dalam mengkomunikasi matematis masih sangat kurang". Secara rinci terdapat 2 faktor yang mempengaruhi rendahnya nilai matematika pada siswa baik faktor internal maupun faktor eksternal . Faktor internal yang mempengaruhi hasil belajar siswa salah satunya adalah kemampuan komunikasi matematis siswa dalam mempelajari materi pelajaran yang diberikan, sedangkan faktor eksternal salah satunya adalah cara guru mengajar, atau model pembelajaran yang digunakan oleh guru dalam pembelajaran di kelas.

Berdasarkan hasil observasi yang dilakukan peneliti di SMP Negeri 2 Hinai terdapat berbagai masalah mengenai keberhasilan kegiatan proses belajar mengajar di kelas. Masalah pertama yang diidentifikasi oleh peneliti di SMP Negeri 2 Hinai adalah ditemukan bahwa guru masih menggunakan model pembelajaran konvensional dimana pembelajaran lebih berpusat pada guru. Guru mendominasi proses belajar dan kurang memberikan kesempatan kepada siswa untuk bertanya dan mengungkapkan pendapatnya perihal materi yang diajarkan tersebut. Kondisi ini mengakibatkan siswa menjadi kurang aktif dan kurang tertarik dalam mengungkapkan ide atau memberi penjelasan dari permasalahan yang diberikan dalam mengikuti pelajaran matematika. Akan berdampak juga dengan kemampuan komunikasi matematis siswa yang kurang berkembang.

Peran guru masih lebih banyak dalam kegiatan pembelajaran dibandingkan siswa. Guru beranggapan bahwa siswa merupakan objek atau sasaran belajar dimana berbagai usaha proses pembelajaran lebih banyak dilakukan oleh guru. Kegiatan seperti mencari, mengumpulkan, memecahkan dan menyampaikan informasi dan permasalahan matematika dilakukan oleh guru. Hal tersebut ditunjukkan hanya agar peserta didik memperoleh pengetahuan.Sehingga mengakibatkan siswa menjadi pasif, dan tidak ada umpan balik dari siswa ke guru dalam kegiatan pembelajaran.

Hal ini ditunjukkan ketika guru sudah selesai menerangkan materi pelajaran, tidak ada satu siswa pun yang bertanya mengenai materi tersebut. Siswa yang diam seolah-olah sudah paham dengan materi tersebut. Namun dalam kenyataannya, ketika guru memberikan soal maka masih banyak siswa yang tidak mampu mengerjakannya dikarenakan siswa yang tidak paham mengenai materi tersebut tidak mengemukakan respon berupa pendapat, kritik atau pertanyaan kepada guru pada saat proses pembelajaran berlangsung.

Berdasarkan hasil observasi juga terdapat siswa yang tidak memperhatikan guru menjelaskan materi di depan kelas. Akibatnya siswa akan kurang maksimal menerima dan memahami materi pelajaran tersebut. Aktivitas siswa hanya mengulang prosedur atau menghafal tanpa memberi peluang lebih banyak untuk berinteraksi dengan sesama yang akan mengakibatkan siswa menjadi bosan. Begitu juga dengan materi yang sulit dipadu dengan pembelajaran yang kurang menarik atau kurang bervariasi juga menjadi salah satu penyebabnya. Kondisi seperti ini didukung dengan hasil observasi siswa kelas VIII SMP Negeri 2 Hinai pada saat proses pembelajaran yang dilakukan guru dimana siswa hanya duduk diam mendengarkan guru yang sedang memaparkan dan menjelaskan materi bahkan siswa tidak terbiasa memberi penjelasan atau ide dari masalah (soal) yang diberikan.

Kenyataan menunjukkan bahwa kemampuan komunikasi matematis siswa masih rendah. Hal ini dilihat berdasarkan tes diagnostik yang diberikan peneliti kepada siswa kelas IX-A SMP Negeri 2 Hinai . Tes diagnostik ini dilakukan peneliti dengan memberikan 3 soal kepada 35 siswa. Ketiga soal ini dirancang agar penyelesaiannya dapat menunjukkan indikator komunikasi

Ariati Dara Anindita, Humuntal Banjarnahor. Perbedaan Kemampuan Komunikasi Matematis Siswa Menggunakan Model Pembelajaran Kooperatif Tipe TPS dengan Tipe NHT SMP Negeri 2 Hinai. Jurnal Inspiratif, Vol. 3 No. 2 Agustus 2017. 
matematis yaitu (representasi, menggambar, menulis/menjelaskan). Diperoleh hasil bahwa 18 siswa $(47,37 \%)$ tergolong dalam kategori sangat rendah , 8 siswa $(21,05 \%)$ tergolong dalam kategori rendah hingga sedang, 7 siswa $(18,42 \%)$ tergolong dalam kategori sedang hingga cukup, 5 siswa $(13,16)$ tergolong dalam kategori cukup hingga baik.

Berikut soal yang diberikan pada penelitian pendahuluan tersebut.

1. Gambarkanlah sebuah balok
ABCD.EFGH dan tentukanlah
bagian-bagian dari :
a. Bidang sisi
b. Titik-titik sudut c. Rusuk
2. Perhatikan gambar kubus di bawah
ini :
Tentukanlah : a. Diagonal bidang
a. Diagonal ruang
Dan jelaskan pengertian diagonal
bidang dan diagonal ruang kubus
tersebut! ang
3. Tentukanlah panjang kawat yang
diperlukan untuk membuat
kerangka balok dengan ukuran
12cm x $8 \mathrm{~cm} x$ cm!

Tabel 1. Data Kesalahan Hasil Pekerjaan Siswa

\begin{tabular}{|c|c|}
\hline Hasil Pekerjaan Siswa & Analisis Kesalahan \\
\hline 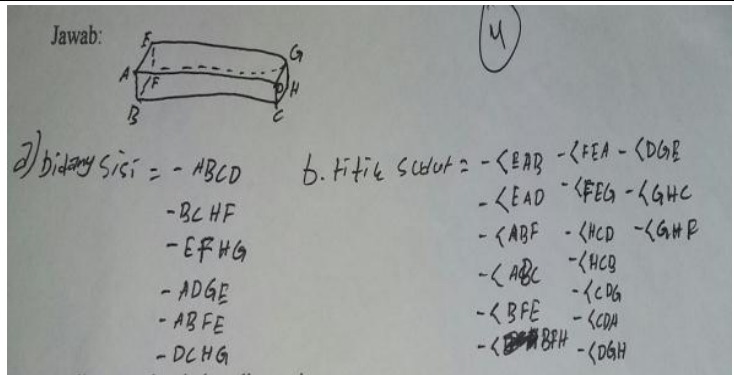 & $\begin{array}{l}\text { Siswa kurang mampu menyatakan ide } \\
\text { matematika melalui tulisan, } \\
\text { demonstrasi secara visual. Tampak } \\
\text { dalam menggambar balok yang masih } \\
\text { berantakan dan tidak mampu } \\
\text { menyebutkan rusuk-rusuk balok } \\
\text { tersebut. }\end{array}$ \\
\hline $\begin{array}{l}\text { awab: } \\
\text { Diagonal bidang: } A B, B C, C D, D A, A E, E F, F G, G H, H E, H D, F B, G C \\
\text { Diagonal ruang: } A C, B D, E G, A G, B H\end{array}$ & $\begin{array}{l}\text { Siswa belum mampu menerangkan ide } \\
\text { (masalah) yang disajikan dalam } \\
\text { tulisan, lisan dan dalam bentuk visual. } \\
\text { Jawaban siswa masih kurang dalam } \\
\text { memahami penjelasan dari } \\
\text { permasalahan yang diberikan. }\end{array}$ \\
\hline $\begin{aligned} K & =p+l+T \times 4 \\
& =12+8+5 \times 4 \\
& =100 \mathrm{~cm}\end{aligned}$ & $\begin{array}{l}\text { Siswa tidak mampu memahami dan } \\
\text { menginterpretasikan ide matematika } \\
\text { dalam bentuk tulisan. Dalam soal yang } \\
\text { ditanya adalah panjang kawat yang } \\
\text { diperlukan, berarti menggunakan } \\
\text { rumus keliling balok, namun siswa } \\
\text { masih salah dalam meletakkan rumus } \\
\text { keliling balok }\end{array}$ \\
\hline
\end{tabular}

Ariati Dara Anindita, Humuntal Banjarnahor. Perbedaan Kemampuan Komunikasi Matematis Siswa Menggunakan Model Pembelajaran Kooperatif Tipe TPS dengan Tipe NHT SMP Negeri 2 Hinai. Jurnal Inspiratif, Vol. 3 No. 2 Agustus 2017. 
Dari Persentase yang diperoleh melalui tes diagnostik tersebut terlihat bahwa kemampuan komunikasi matematis siswa masih rendah karena hanya terdapat 5 orang siswa yang tergolong kategori cukup hingga baik.

Kemampuan komunikasi antara guru dan siswa maupun siswa dengan siswa sangat penting dalam proses belajar mengajar untuk tercapainya tujuan pembelajaran. Menyadari akan pentingnya kemampuan komunikasi matematis maka sebagai pendidik perlu mengupayakan pembelajaran dengan menggunakan model pembelajaran yang dapat memberi peluang dan mendorong mahasiswa untuk melatihkan kemampuan komunikasi matematis. Hal tersebut sesuai dengan pendapat Ozsoy dan Yildiz (2004) bahwa siswa tidak hanya membutuhkan pengetahuan tetapi juga keterampilan komunikasi, keterampilan pemecahan masalah, kreatif dan keterampilan berpikir kritis dalam

tahun-tahun mendatang. Komunikasi matematis akan berperan efektif manakala guru mengkondisikan siswa agar mendengarkan secara aktif sebaik mereka mempercakapkannya. Untuk itu, dari masalah yang diungkapkan diatas maka diperlukan model pembelajaran yang dapat meningkatkan kemampuan komunikasi matematis.

Penggunaan model pembelajaran yang tepat akan dapat mengatasi kejenuhan dalam menerima pelajaran matematika. Seperti yang dikatakan oleh Trianto (2009: 12) bahwa : Model-model pembelajaran inovatif-progesif merupakan konsep belajar yang melatih guru dalam mengaitkan antara materi yang diajarkan dengan situasi dunia nyata siswa dan mendorong siswa membuat hubungan antara pengetahuan yang dimilikinya dengan penerapannya dalam kehidupan mereka sebagai anggota keluarga dan masyarakat.

Akinsola dan Olowojaiye (2008) yang menyatakan bahwa cara guru dalam penyampaian pembelajaran di kelas sangat berpengaruh dalam mengubah sikap dan kebiasaan siswa dalam belajar matematika. Model pembelajaran yang diharapkan saat ini adalah model pembelajaran yang bisa mengajak siswa untuk aktif dalam pembelajaran, menyenangkan dan melibatkan siswa dalam proses pembelajaran, sehingga pengetahuan yang didapatnya tidak akan mudah hilang dan bermakna bagi siswa.

Dengan menggunakan model pembelajaran yang inovatif, diharapkan siswa dapat memahami konsep dari materi pelajaran. Dengan konsep itu, hasil pembelajaran diharapkan lebih bermakna bagi siswa. Dengan begitu proses pembelajaran berlangsung alamiah dalam bentuk kegiatan siswa bekerja dan mengalami, bukan mentransfer pengetahuan dari guru ke siswa. Salah satu model pembelajaran yang diharapkan dapat menjadi pembelajaran yang bermakna bagi siswa adalah pembelajaran kooperatif.

$$
\text { Pembelajaran kooperatif }
$$

merupakan strategi belajar dengan sejumlah siswa sebagai anggota kelompok kecil yang tingkat kemampuannya berbeda. Dalam menyelesaikan tugas kelompoknya, setiap siswa anggota kelompok harus saling bekerja sama dan saling membantu untuk memahami materi pelajaran. Dalam pembelajaran kooperatif, belajar dikatakan belum selesai jika salah satu teman dalam kelompok belum menguasai bahan pelajaran (Isjoni, 2009:14-15).

. Zakaria et al (2010) menyatakan

bahwa pembelajaran kooperatif merupakan pendekatan yang efektif, guru matematika perlu memasukkan dalam pengajaran mereka. Pembelajaran kooperatif adalah sebuah proses pembelajaran yang melibatkan siswa dalam pembelajaran, dimana siswa dilatih untuk bisa dan mau bekerja sama dalam kelompok-kelompok kecil untuk mencapai tujuan bersama. Selanjutnya Hossain, dkk (2012) menyatakan bahwa, "Penggunaan pembelajaran kooperatif dapat meningkatkan prestasi matematika dan kemampuan komunikasi siswa".

Model pembelajaran kooperatif memiliki konsep belajar berkelompok

Ariati Dara Anindita, Humuntal Banjarnahor. Perbedaan Kemampuan Komunikasi Matematis Siswa Menggunakan Model Pembelajaran Kooperatif Tipe TPS dengan Tipe NHT SMP Negeri 2 Hinai. Jurnal Inspiratif, Vol. 3 No. 2 Agustus 2017. 
yang mampu membuat siswa aktif dan kritis dalam pembelajaran karena dengan belajar berkelompok siswa akan bertanya mengenai materi pelajaran yang tidak diketahui kepada temannya tanpa rasa malu. Pembelajaran kooperatif dikenal dengan pembelajaran secara berkelompok. Tetapi belajar kooperatif lebih dari sekedar belajar kelompok atau kerja kelompok karena dalam belajar kooperatif ada struktur dorongan atau tugas yang bersifat kooperatif sehingga memungkinkan terjadinya interaksi secara terbuka dan hubungan yang bersifat interdepedensi efektif diantara anggota kelompok.

Dalam hal ini penulis memilih dua tipe pembelajaran yaitu model pembelajaran kooperatif tipe TPS dan NHT.

Shoimin (2016:208) menyatakan bahwa " Think Pair Share adalah suatu model pembelajaran kooperatif yang memberi siswa waktu untuk berpikir dan merespon serta saling bantu satu sama lain". Terdapat ide waktu berpikir atau waktu tunggu dalam model ini yang menjadi faktor kuat dalam meningkatkan kemampuan siswa dalam merespons pertanyaan. Pembelajaran kooperatif model Think Pair Share ini relatif lebih sederhana karena tidak menyita waktu yang lama untuk mengatur tempat duduk ataupun mengelompokkan siswa. Model pembelajaran ini melatih siswa untuk berani berpendapat dan menghargai pendapat teman. Strategi Think Pair Share (TPS) atau berpikir berpasangan berbagi merupakan jenis pembelajaran kooperatif yang dirancang untuk memengaruhi pola interaksi siswa.

Selain model pembelajaran kooperatif tipe Think Pair Share (TPS), model pembelajaran kooperatif tipe Numbered Head Together (NHT) juga dirancang untuk mempengaruhi pola interaksi siswa. NHT sering dikenal dengan sebutan "Kepala Bernomor", maksudnya setiap individu pada masingmasing kelompok diberi nomor. Model pembelajaran NHT merupakan model pembelajaran kooperatif yang terdiri cukup banyak anggota dalam tiap kelompoknya (Nasikhah, 2011: 392). Sangat dibutuhkan kerjasama kelompok untuk mencapai tujuan pembelajaran. Semua anggota kelompok mempunyai peran untuk saling menjelaskan kepada anggota yang lain. Hal ini akan membantu siswa dalam berlatih untuk berkomunikasi kepada orang lain.

Kedua tipe model pembelajaran ini mengedepankan perlunya siswa mengkomunikasikan atau menjelaskan hasil pemikiran matematikanya. Dua model pembelajaran ini juga sama-sama merupakan model pembelajaran kooperatif (model pembelajaran berkelompok), tetapi dua model pembelajaran kooperatif ini memiliki perbedaan. Perbedaan dari dua model pembelajaran kooperatif tipe TPS dan NHT tersebut dapat di lihat mulai dari pengertian, sintaks dan jumlah anggota dalam kelompoknya. Tidak hanya itu, kedua model pembelajaran kooperatif tersebut memiliki kelebihan dan kelemahan masing-masing dalam proses pembelajaran.

Dengan menerapkan model pembelajaran kooperatif tipe TPS dan NHT diharapkan dapat membangkitkan keterkaitan siswa terhadap materi matematika dan membuat siswa lebih aktif, mendorong kerja sama antar siswa dalam mempelajari suatu materi, sehingga dapat meningkatkan kemampuan komunikasi matematis siswa. Namun diantara kedua tipe model pembelajaran ini, akan diteliti manakah model pembelajaran kooperatif yang lebih efektif sehingga dapat diterapkan dalam proses pembelajaran untuk meningkatkan kemampuan komunikasi matematis siswa.

Dari kedua model pembelajaran tersebut peneliti bermaksud mengadakan penelitian untuk melihat perbedaan model pembelajaran kooperatif tipe TPS dan kooperatif tipe NHT terhadap kemampuan komunikasi matematis siswa. Untuk pemilihan materi, penulis memilih materi kubus dan balok dimana masih kurangnya pemahaman siswa terhadap materi tersebut. Berdasarkan diuraikan diatas, peneliti bermaksud mengadakan penelitian berjudul :"Perbedaan

Ariati Dara Anindita, Humuntal Banjarnahor. Perbedaan Kemampuan Komunikasi Matematis Siswa Menggunakan Model Pembelajaran Kooperatif Tipe TPS dengan Tipe NHT SMP Negeri 2 Hinai. Jurnal Inspiratif, Vol. 3 No. 2 Agustus 2017. 
Kemampuan Komunikasi Matematis Siswa Menggunakan Model Pembelajaran Kooperatif Tipe TPS dengan Tipe NHT SMP Negeri 2 Hinai".

\section{Metode Penelitian}

Penelitian ini dilaksanakan di SMP Muhammadiyah 2 Hinai yang berlokasi di di Jl. Perjuangan Pasar 4,5 Hinai- Langkat pada semester genap tahun ajaran 2016/2017. Variabel bebas dalam penelitian ini adalah pembelajaran dengan menggunakan model pembelajaran kooperatif tipe TPS dan NHT. Sedangkan variabel terikatnya adalah kemampuan komunikasi matematis siswa.

Jenis penelitian yang digunakan dalam penelitian ini adalah eksperimen semu yang bertujuan untuk mengetahui perbedaan kemampuan komunikasi matematis siswa yang diajar menggunakan model pembelajaran kooperatif tipe TPS dan NHT di Kelas VIII SMP Negeri 2 Hinai. Populasi dalam penelitian ini adalah seluruh siswa kelas VIII yang terdiri dari 7 kelas. Sedangkan sampelnya terdiri dari 34 siswa pada kelas VIII-A dan 34 siswa pada kelas VIII-D. Desain penelitian yang digunakan dalam penelitian ini adalah Post-Test Only Control Group Design. Instrumen yang digunakan dalam penelitian ini adalah tes kemampuan komunikasi matematis siswa (post-test). Analisis data dalam penelitian ini terdiri dari pengujian normalitas, pengujian homogenitas, dan pengujian hipotesis.

\section{Hasil Penelitian dan Pembahasan}

Sebelum penelitian ini dilaksanakan, peneliti terlebih dahulu mengujicobakan instrumen-instrumen penelitian diluar sampel penelitian. Untuk menafsirkan keberartian harga validitas setiap item soal, maka harga $r_{\text {hitung }}$ tersebut dibandingkan dengan nilai $r_{\text {tabel }}(0,344)$, dengan kriteria jika $r_{\text {hitung }}>r_{\text {tabel }}$, maka soal dinyatakan valid. Perhitungan reliabilitas soal post-test, diperoleh $\mathrm{r}_{\text {hitung }}$ $(0,5227)$ sehingga $r_{\text {hitung }}>r_{\text {tabel }}$ dikatakan reliabel. Dari perhitungan uji validitas dan reliabilitas tes yang dinyatakan valid dan reliabel, maka seluruh soal post-test kemampuan komunikasi matematis siswa dapat dipakai untuk penelitian ini.

Setelah kedua kelas diberi perlakuan yang berbeda yaitu dengan model pembelajaran kooperatif tipe TPS untuk kelas Eksperimen 1 dan model pembelajaran kooperatif tipe NHT untuk kelas Eksperimen 2, kemudian siswa diberikan post-test untuk mengetahui kemampuan komunikasi matematis. Dari hasil penelitian diperoleh nilai rata-rata post-test pada kelas Eksperimen 1 adalah 67,01 dan nilai rata-rata post-test pada kelas Eksperimen 2 adalah 60,54. Berdasarkan hasil analisis data post-test diperoleh kedua kelas memiliki nilai $L_{0}<L_{\text {tabel }}$ yaitu $0,1291<0,1519$ (kelas Eksperimen 1) dan 0,1431<0,1519 (kelas Eksperimen 2) sehingga dapat disimpulkan kelas Eksperimen 1 dan kelas Eksperimen 2 berdistribusi normal. Pada pengujian homogenitas diperoleh $F_{\text {hitung }}<F_{\text {tabel }}$ yaitu $1,13<1,42$ sehingga dapat disimpulkan bahwa kedua sampel homogen.

Selanjutnya dilakukan pengujian hipotesis dengan menggunakan uji $t$. Setelah dilakukan pengujian data ternyata diperoleh $t_{\text {hitung }}>t_{\text {tabel }}$ yaitu $1,913>$ 1,669 maka $H_{0}$ ditolak dan $H_{a}$ diterima. Dengan demikian dapat disimpulkan bahwa kemampuan komunikasi matematis siswa menggunakan model pembelajaran kooperatif tipe TPS lebih tinggi daripada kemampuan komunikasi matematis siswa menggunakan model pembelajaran kooperatif tipe NHT SMP Negeri 2 Hinai.

Selama proses pembelajaran di kedua kelas pun, peneliti memperhatikan bagaimana karakteristik siswa ketika berdiskusi dengan timnya. Pada kelas eksperimen 1 dengan menggunakan model pembelajaran kooperatif tipe TPS yang merupakan model pembelajaran yang baik dalam merangsang siswa mengembangkan idenya untuk mengkomunikasikan gagasannya. Siswa lebih leluasa untuk menyampaikan

Ariati Dara Anindita, Humuntal Banjarnahor. Perbedaan Kemampuan Komunikasi Matematis Siswa Menggunakan Model Pembelajaran Kooperatif Tipe TPS dengan Tipe NHT SMP Negeri 2 Hinai. Jurnal Inspiratif, Vol. 3 No. 2 Agustus 2017. 
gagasannya dengan pasangan kelompoknya. Masing-masing pasangan kelompok memiliki hak yang sama untuk mengutarakan pendapatnya. Karena memiliki pola berpasangan, membuat anggota dalam kelompok tidak merasa canggung dan takut untuk saling berbagi pendapat guna menyelesaikan soal yang diberikan kepada guru dengan pasangannya baik dalam berdiskusi ataupun ketika mempersentasikan hasil diskusinya. Sedangkan untuk kelas eksperimen 2 dengan menggunakan model pembelajaran kooperatif tipe NHT dengan membagi masing-masing kelompok beranggotakan 4-5 orang kurang cocok dengan jumlah siswa yang relatif banyak. Padahal jika dipandang dari segi jumlah anggota kelompok yang lebih banyak dan memberikan nomor kepala kepada tiap anggota kelompok , yang mengharuskan setiap nomor kepala harus mempertanggung jawabkan jawaban masing-masing kelompok jika nomor perkepala disebutkan akan membuat setiap siswa dapat mengkomunikasikan gagasannya secara baik. Namun kenyataannya di kelas eksperimen 2, banyak siswa yang belum mampu mempertanggung jawabkan jawaban perkelompoknya jika guru memanggil nomor kepala kelompoknya. Siswa masih lebih takut untuk menyuarakan pendapatnya sendiri jika dipanggil, siswa juga kurang aktif dalam berdiskusi dikarenakan mereka beranggapan tinggal menerima bersih jawaban kelompok dan hanya 1-2 orang saja anggota kelompok yang mengerjakannya. Hal ini dikarenakan siswa lebih santai karena beranggapan anggota dalam kelompoknya sudah banyak dan pasti jawaban akan selesai dengan sendirinya. Kurangnya tanggung jawab yang ditunjukkan inilah yang membuat siswa kurang mampu menyelesaikan permasalahan yang ada karena tidak terjadi diskusi atau penyampaian ide dan pendapat yang diharapkan untuk menyelesaikan permasalahan yang ada sehingga model NHT pada kelas eksperimen 2 kurang berjalan seperti yang diharapkan.
Untuk memperkuat hasil penelitian ini maka dibandingkan dengan penelitian yang relevan yang dilakukan Penelitian yang dilakukan oleh Qisthiani Nasikhah dan Mujiyem Sapti dalam jurnal yang berjudul "Eksperimentasi Model Pembelajaran TPS (Think Pair Share) Terhadap Prestasi Belajar Matematika Ditinjau Dari Kemampuan Komunikasi Matematika Siswa Kelas VII SMP SeKecamatan Purworejo", menyimpulkan bahwa Uji hipotesis menunjukkan bahwa (1) pembelajaran menggunakan model pembelajaran tipe TPS (Think Pair Share) menghasilkan prestasi belajar matematika yang lebih baik daripada tipe NHT (Numbered Head Together) pada sub materi pokok persegi panjang dan persegi siswa kelas VII SMP se-Kecamatan Purworejo.

Apabila penelitian Nasikhak dibandingkan dengan penelitian ini, dapat diketahui bahwa penelitian ini dan penelitian Nasikhak memiliki kesamaan dimana rata-rata nilai postest kelas eksperimen dengan model pembelajaran kooperatif tipe TPS lebih tinggi dari model pembelajaran kooperatif tipe NHT dilihat dari kemampuan komunikasi siswa. Dengan demikian dapat disimpulkan bahwa kemampuan komunikasi matematis siswa menggunakan model pembelajaran kooperatif tipe TPS lebih tinggi dari model pembelajaran kooperatif tipe NHT dilihat dari kemampuan komunikasi siswa SMP Negeri 2 Hinai.

Berdasarkan hasil penelitian dan penelitian yang relevan membuktikan bahwa penggunaan model pembelajaran kooperatif tipe TTW (Think Talk Write) lebih tinggi daripada tipe NHT (Numbered Head Together).

\section{Kesimpulan}

Berdasarkan hasil penelitian dan pengolahan data maka dapat ditarik kesimpulan : dari hasil uji hipotesis diperoleh bahwa $\mathrm{t}_{\text {hitung }}=1,913$ dan $\mathrm{t}_{\text {tabel }}=$ 1,669 maka diperoleh bahwa $t_{\text {hitung }}>t_{\text {tabel }}$ terlihat yang berati bahwa $\mathrm{H}_{0}$ ditolak dan

Ariati Dara Anindita, Humuntal Banjarnahor. Perbedaan Kemampuan Komunikasi Matematis Siswa Menggunakan Model Pembelajaran Kooperatif Tipe TPS dengan Tipe NHT SMP Negeri 2 Hinai. Jurnal Inspiratif, Vol. 3 No. 2 Agustus 2017. 
$\mathrm{H}_{\mathrm{a}}$ diterima. Maka disimpulkan bahwa kemampuan komunikasi matematis siswa menggunakan model pembelajaran kooperatif tipe TPS lebih tinggi daripada kemampuan komunikasi matematis siswa menggunakan model pembelajaran kooperatif tipe NHT SMP Negeri 2 Hinai.

\section{Saran}

Berdasarkan hasil penelitian ini maka saran yang dapat peneliti berikan adalah:

1. Bagi guru matematika dapat menggunakan model pembelajaran kooperatif tipe Think Pair Share (TPS) sebagai salah satu alternatif pembelajaran dalam upaya meningkatkan kemampuan komunikasi matematis siswa dalam proses pembelajaran sehingga siswa lebih mudah dan mampu dengan sendirinya memahami dan mempelajari materi yang diajarkan.

2. Bagi guru-guru atau calon guru yang akan menerapkan model pembelajaran kooperatif agar memperhatikan dan mengatur alokasi waktu yang ada secara cermat agar langkah-langkah pembelajaran dapat dilaksanakan secara optimal.

\section{DAFTAR PUSTAKA}

Akinsola, M. K. and Olowojaiye, F. B., (2008), Teacher Instructional Methods and Student Attitudes towards Mathematics, International Electronic Journal of Mathematics education, 3 (1) : 60-73.

Hossain, M.A., Tarmizi, R.A., and Ayub, A.F., (2012), Collaborative and Cooperative Learning in Malaysian Mathematics Education, IndoMS.J.M.E, 3 (2) : 103-114

Isjoni, (2009), Cooperative Learning Efektifitas Pembelajaran Kelompok,Alfabeta, Bandung.
Istarani, (2011), 58 Model Pembelajaran Inovatif, Media Persada, Medan.

Martunis, dkk, (2014), Meningkatkan Kemampuan Pemahaman dan Komunikasi Matematis Siswa Sekolah Menengah Atas melalui Model Pembelajaran Generatif, Jurnal ISSN : 2355-4185.

Muhammad Darkasyi, dkk, 2014, Peningkatan Kemampuan komunikasi Matematis dan Motivasi Siswa dengan Pembelajaran Pendekatan Quantum Learning pada siswa SMP Negeri 5 Lhoksumawe, Jurnal ISSN : 2355-4185.

Nasikhah, Qisthiani dan Sapti, Mujiyem, 2011, Eksperimentasi Model Pembelajaran Tps (Think Pair Share) Terhadap Prestasi Belajar Matematika Ditinjau Dari Kemampuan Komunikasi Matematika Siswa Kelas VII Smp Se-Kecamatan Purworejo, Prosiding Seminar Nasional Matematika dan Pendidikan Matematika Yogyakarta, 3 Desember 2011 ISBN: 978-979-16353-6-3 .

Ojose, B., (2011), Mathematics Literacy: Are We Able To Put The Mathematics We Learn Into Everyday Use?,Journal of Mathematics Education, 4 (1): 89-100.

Ozsoy, N. andYildiz, N.,(2004), The Effect of Learning Together Technique of Cooperative Learning Method On Student Achievement In Mathematics Teaching 7th Class of Primary School. The Turkish Online Journal of Educational Technology, 3 (3): 49-54.

Sefalianti, Berta, (2014), Penerapan Pendekatan Inkuiri Terbimbing Terhadap Kemampuan

Ariati Dara Anindita, Humuntal Banjarnahor. Perbedaan Kemampuan Komunikasi Matematis Siswa Menggunakan Model Pembelajaran Kooperatif Tipe TPS dengan Tipe NHT SMP Negeri 2 Hinai. Jurnal Inspiratif, Vol. 3 No. 2 Agustus 2017. 
Komunikasi dan Disposisi

Matematis Siswa, Jurnal

Pendidikan dan Keguruan Vol. 1

No.2.

Shoimin, Aris, (2016) , 68 Model Pembelajaran Inovatif dalam Kurikulum 2013, Ar-Ruzz Media, Yogyakarta .

Surya, E. Josua Sabandar, Yahya Sukjaya Kusumah, Darhim. (2013). Improving of junior High School Visual Thinking Representation Ability in Mathematical Problem Solving by CTL. Indonesian Mathematical Society Journal on Mathematics Education 4(1), 113-126.

Surya, E., Putri, F.A. Mukhtar. (2017). Improving Mathematical Problem Solving Abilitry and Self-Confidence of High School Students Through Contextual Learning Model. Indonesian Mathematical Society Jounal on Mathematics Education, 8(1), 85-94.

Trianto, (2009), Mendesain Model Pembelajaran InovatifProgresif, Kencana Prenada Media Group, Jakarta.

Zakaria, E., Chin, L. C., and Daud, Y., (2010), The Effects of Cooperative Learning on Students' Mathematics Achievement and Attitude towards Mathematics, Journal of Social Sciences, 6 (2): 272275.

Ariati Dara Anindita, Humuntal Banjarnahor. Perbedaan Kemampuan Komunikasi Matematis Siswa Menggunakan Model Pembelajaran Kooperatif Tipe TPS dengan Tipe NHT SMP Negeri 2 Hinai. Jurnal Inspiratif, Vol. 3 No. 2 Agustus 2017. 